Available online at GSC Online Press Directory

GSC Biological and Pharmaceutical Sciences

e-ISSN: 2581-3250, CODEN (USA): GBPSC2

Journal homepage: https://www.gsconlinepress.com/journals/gscbps

(RESEARCH ARTICLE)

\title{
A pilot study of DNA yield from bloodstains on various surfaces using Phenol chloroform isoamyl alcohol (PCIA) and Chelex DNA extraction methods
}

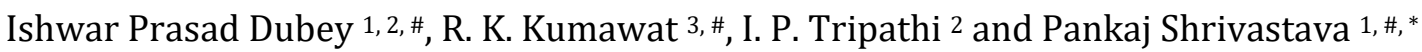 \\ ${ }^{1}$ DNA Fingerprinting Unit, State Forensic Science Laboratory, Sagar-470001, Madhya Pradesh, India. \\ ${ }^{2}$ Faculty of Science and Environment, MGCGV, Chitrakoot, Satna - 485334, Madhya Pradesh, India. \\ ${ }^{3}$ DNA Division, State Forensic Science Laboratory, Rajasthan, Jaipur, India. \\ \# Authors with equal credential.
}

Publication history: Received on 08 November 2020; revised on 15 November 2020; accepted on 16 November 2020

Article DOI: https://doi.org/10.30574/gscbps.2020.13.2.0363

\begin{abstract}
Presently, Short Tandem Repeats (STRs) based forensic DNA typing technology is being globally used in solving a diverse range of forensic cases such as paternity, identification of unknown dead bodies/skeletal remains, or suspect in a case of rape or mass rape. The technology has invaded its tentacles in almost all areas of criminal investigation in the last few decades. The present forensic DNA technology is based on capillary electrophoresis and utilizes short tandem repeats(STRs).On one hand, the technology is extensively used in the investigation of crime in highly sensitive cases, but on the another hand, obtaining DNA profile from forensic samples are highly challenging many times. Advent of PCR has been a boon for handling the challenging samples in forensic DNA analysis. The quality DNA profiles from challenging samples rely on the yield and quality of DNA, which is mainly dependent upon the method used for DNA extraction. Any specific method can never be thought of to be useful for all variety of samples. Still, Phenol Chloroform Isoamyl Alcohol (PCIA) organic extraction method has been proven to be useful for a wide variety of samples from the simplest saliva/blood to complex teeth and bone samples. In the present study, we compared the yield of DNA from blood stains recovered from various surfaces using the PCIA extraction method and Chelex DNA extraction methods and their compatibility with present-day STR based capillary electrophoresis typing. The mean value of DNA yield was found $50.5 \mathrm{ng} / \mu \mathrm{l}$ and $32.25 \mathrm{ng} / \mu \mathrm{l}$ by PCIA and Chelex DNA extraction methods, respectively. Overall, the highest yield was observed from all the tested samples from the PCIA method.
\end{abstract}

Keywords: DNA Yield; Forensic; Phenol Chloroform Isoamyl Alcohol; Chelex

\section{Introduction}

The most popular short tandem repeats (STR's),polymerase chain reaction (PCR) and Capillary Electrophoresis (CE) based DNA analysis technology is being widely used in forensic casework analysis [1-2] as well as in anthropological, population genetic [3-4], and medical studies [5-6]. The STR based DNA analysis technology is entirely different from the original, almost 30 years old methodology known as Restriction Fragment Length Polymorphism (RFLP) of DNA application in forensic science[7]which is obsolete now from forensic casework analysis. Presently, STR technology is in common use for forensic applications due to their high combined discrimination power as they have high repeat numbers, (once in approximately every 10,000 nucleotides) constituting about three percent of the total human genome[8]. Multiplexing of short tandem repeat markers is easy to use and therefore worldwide large number of population STR data is available and presently more than 20 markers STR multiplex systems are being used in forensic DNA typing and/or in casework analysis. Overall to obtain good quality DNA profiles from various forensic samples, an

${ }^{*}$ Corresponding author: Pankaj Shrivastava

DNA Fingerprinting Unit, State Forensic Science Laboratory, Sagar-470001, Madhya Pradesh, India.

Copyright (C) 2020 Author(s) retain the copyright of this article. This article is published under the terms of the Creative Commons Attribution Liscense 4.0. 
appropriate quantity of amplifiable DNA is required. In forensic casework analysis blood stains are encountered on various surfaces. Therefore, to evaluate the DNA yield from bloodstains recovered from eight different surfaces using PCIA and Chelex DNA extraction methods, this study was undertaken.

\section{Material and methods}

In this study, blood stains from various surfaces namely cloth piece, cemented floor, wooden piece, iron pipe, knife, stone, glass surface, and soil were used for DNA extraction using PCIA and Chelex DNA extraction methods as per standard recommendations[9]. We took an equal amount of stains for both methods. The tested stain samples were taken from routine case examination at State Forensic Science Laboratory, Sagar, Madhya Pradesh, India in the year 2014.

Triplicate of each tested sample was processed using both the DNA extraction methods i.e., PCIA and Chelex. The yield of DNA was quantified by Quantifiler ${ }^{\circledR}$ DNA Quantification Kit (Thermo Fisher Scientific, USA) using Real-Time PCR 7000 system (Thermo Fisher Scientific, USA).

\section{Results and discussion}

The average value of DNA yield (ng/ $\mu \mathrm{l}$ ) from bloodstains recovered from cloth piece, cemented floor, wooden piece, iron pipe, knife, stone, glass surface, and soil were 50.5, 40.25, 35.12, 42.05, 43.25, 33.26, 45.78, and 30.23 (ng/ $\mu \mathrm{l}$ ) respectively from the PCIA method. The average value of DNA yield $(\mathrm{ng} / \mu \mathrm{l})$ from bloodstains recovered from cloth piece, cemented floor, wooden piece, iron pipe, knife, stone, glass surface, and soil were 28.56, 22.78, 18.23, 21.02, 20.25, $19.25,23.26$ and 12.29 (ng/ $\mu \mathrm{l}$ ) respectively from the Chelex method (Table 1).

Table 1 Comparative average yield of DNA from various surfaces using PCIA and Chelex method

\begin{tabular}{|l|c|c|}
\hline Surface of blood stains & $\begin{array}{c}\text { Phenol Chloroform Isoamyl } \\
\text { Alcohol (PCIA) method } \\
(\mathbf{n g} / \boldsymbol{\mu l})\end{array}$ & $\begin{array}{c}\text { Chelex Method } \\
(\mathbf{n g} / \boldsymbol{\mu l})\end{array}$ \\
\hline Cloth piece & 50.5 & 28.56 \\
\hline Cemented floor & 40.25 & 22.78 \\
\hline Wooden piece & 35.12 & 18.23 \\
\hline Iron pipe & 42.05 & 21.02 \\
\hline Knife & 43.25 & 20.25 \\
\hline Stone & 33.26 & 19.25 \\
\hline Glass surface & 45.78 & 23.26 \\
\hline soil & 30.23 & 12.29 \\
\hline
\end{tabular}

The highest average yield of DNA $(50.5 \mathrm{ng} / \mu \mathrm{l})$ was obtained from bloodstains on cloth piece whereas the lowest average yield of DNA $(30.23 \mathrm{ng} / \mu \mathrm{l})$ was obtained from soil sample with the use of the PCIA method. In the Chelex method, the highest average yield of DNA $(28.56 \mathrm{ng} / \mu \mathrm{l})$ was obtained from bloodstains on cloth piece whereas the lowest average yield of DNA $(12.29 \mathrm{ng} / \mu \mathrm{l})$ was obtained from the soil sample. In this comparative study average DNA yield using both the DNA extraction method is presented in figure 1. Comparatively higher DNA yield was observed in DNA extraction using PCIA method for all the samples.

The statistical evaluation of obtained results were done using GraphPad Prism v5.03 Software (https://www.graphpad.com/scientific-software/prism/). In this comparison, mean DNA yield from the all the variety of tested samples were evaluated. The overall mean value of DNA yield (ng/ $\mu \mathrm{l})$ from bloodstains recovered from cloth piece, cemented floor, wooden piece, iron pipe, knife, stone, glass surface, and soil was observed higher in PCIA method in comparison with Chelex method. The statistical evaluation of obtained results is presented in figure 2 . Highest and lowest yield was observed from cloth piece and soil samples, respectively. Soil sample is already reported to carry PCR inhibitors. Though, there have been increasing use of automation these days but the PCIA is still a method of choice for 
samples which is supposed to have very low amount of DNA. The phenol chloroform extraction method has already been reported to have its supremacy over other methods of DNA extraction in many comparisons made earlier on wide range of samples including anthropological and clinical samples. For the analysis of forensic samples as well the PCIA method is preferred method and/or method of choice of experienced forensic DNA analysts.

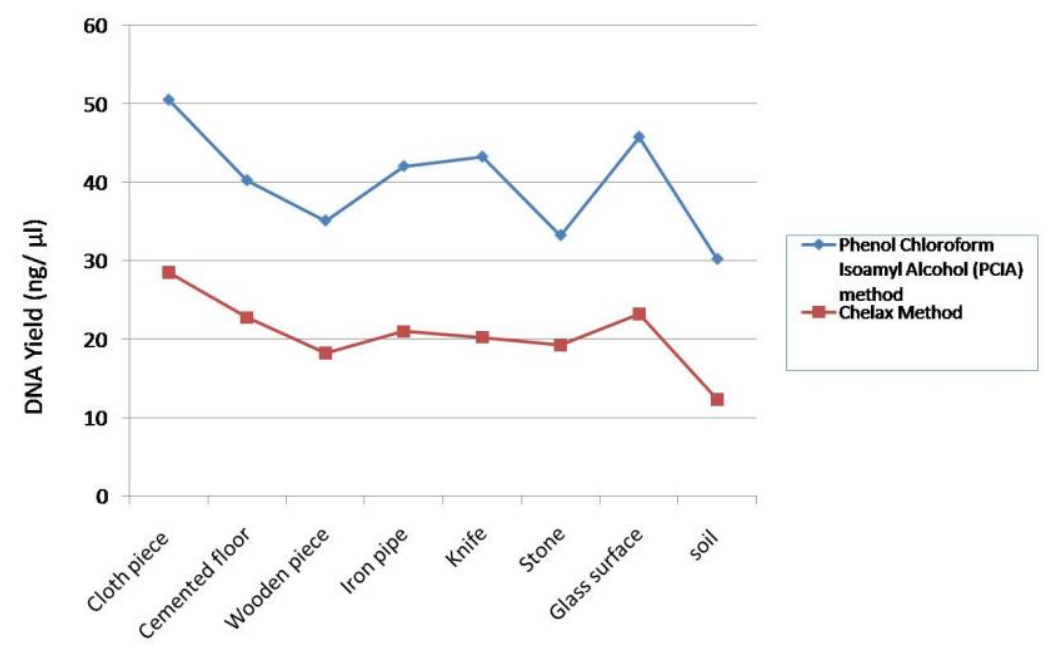

Figure 1 Comparative average yield of DNA(ng/ $\mu \mathrm{l})$ from various surfaces using PCIA and Chelex method

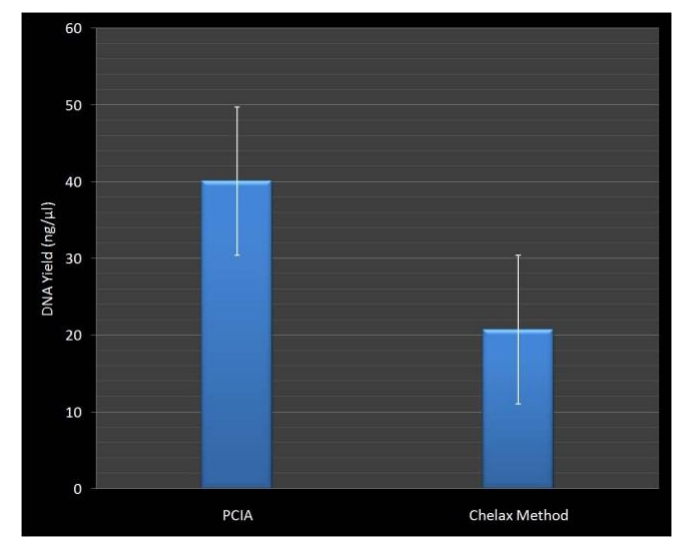

Figure 2 Comparative mean yield of DNA $(\mathrm{ng} / \mu \mathrm{l})$ and standard error from various surfaces using PCIA and Chelex method

\section{Conclusion}

The yield of DNA from bloodstains on various surfaces i.e., cloth piece, cemented floor, wooden piece, Iron pipe, Knife, stone, glass surface, and soil encountered in various crimes was observed higher in Phenol Chloroform Isoamyl Alcohol (PCIA) method than the Chelex method. The observations of the study strongly suggest that for the forensic samples, where chance of getting DNA is low, the PCIA method should be preferred than Chelex method.

\section{Compliance with ethical standards}

\section{Acknowledgments}

The authors acknowledge Dr. Veena Ben Trivedi, Ex. Joint Director and Incharge, DNA Fingerprinting Unit for motivation and the Director, State Forensic Science Laboratory, Sagar (MP) India for permitting laboratory facility for the analysis.

\section{Disclosure of conflict of interest}

Authors declared that they have no conflict of interest 


\section{References}

[1] Thakar MK, Joshi B, Shrivastava P, et al (2019) An assessment of preserved DNA in decomposed biological materials by using forensic DNA profiling. Egypt J Forensic Sci 9:46

[2] Shrivastava P, Trivedi V Ben, Jain T, Ali M (2016) An unusual occurrence of repeated single allele variation on YSTR locus DYS458. Egypt J Forensic Sci 6:289-291

[3] Kumawat RK, Shrivastava P, Shrivastava D, et al (2020) Genomic blueprint of population of Rajasthan based on autosomal STR markers. Ann Hum Biol 1-6

[4] Kumawat RK, Shrivastava P, Shrivastava D, Mathur GK (2020) Molecular diversity of 23 Y-STR genetic markers in the population of Rajasthan, India. Meta Gene 100694

[5] Shrivastava P, Jain T, Trivedi V Ben (2016) DNA fingerprinting: A substantial and imperative aid to forensic investigation. Eur J Forensic Sci 3:23

[6] Edwards AL, Hammond HA, Jin L, et al (1992) Genetic variation at five trimeric and tetrameric tandem repeat loci in four human population groups. Genomics 12:241-253

[7] Jeffreys AJ, Brookfield JFY, Semeonoff R (1985) Positive identification of an immigration test-case using human DNA fingerprints. Nature 317:818

[8] Butler JM (2005) Forensic DNA typing: biology, technology, and genetics of STR markers. Elsevier

[9] Willard JM, Lee DA, Holland MM (1998) Recovery of DNA for PCR amplification from blood and forensic samples using a chelating resin. In: Forensic DNA profiling protocols. Springer, pp 9-18 